\title{
Congenital Horner syndrome
}

INSERM

\section{Source}

INSERM. (1999). Orphanet: an online rare disease and orphan drug data base. Congenital Horner syndrome. ORPHA:91413

Cong enital Horner syndrome is a rare neurological disorder characterized by relative pupillary miosis and blepharoptosis, evident at birth, caused by interruption of the oculosympathetic innervation at any point along the neural pathway from the hypothalamus to the orbit. Often additional symptoms, such as enophthalmos, facial anhidrosis, iris heterochromia, conjunctival congestion, transient hypotonia and/or pupillary dilation lag, may be present. Association with birth trauma, neoplasms or vascular malformations has been reported. 